\begin{tabular}{|c|c|c|}
\hline \multirow[b]{2}{*}{ एवT } & Int.J.Curr.Microbiol.App.Sci (2021) 10(11): 133-141 & \\
\hline & $\begin{array}{l}\text { International Journal of Current Microbiology and Applied Sciences } \\
\text { ISSN: 2319-7706 Volume } 10 \text { Number } \mathbf{1 1}(\mathbf{2 0 2 1 )} \\
\text { Journal homepage: } \underline{\text { http://www.ijcmas.com }}\end{array}$ & 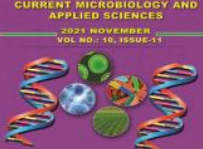 \\
\hline $\begin{array}{l}\text { EXCELLENT } \\
\text { PUBLISHERS }\end{array}$ & & \\
\hline
\end{tabular}

\title{
Phenotypic Stability Analysis for Seed Yield and its Associated Traits in Advanced Lines of Indian Mustard (Brassica juncea L. Czern and Coss)
}

\author{
Danisa Dube*, Th. Renuka Devi, Ph. Ranjit Sharma and N. B. Singh \\ Department of Agriculture, Central Agricultural University, Iroisemba, Imphal, \\ Manipur - 795 004, India \\ *Corresponding author
}

\begin{tabular}{|l|}
\hline Ke y w o r d s \\
$\begin{array}{l}\text { Indian mustard, G } \\
\text { X E interaction, } \\
\text { Phenotypic Stability }\end{array}$ \\
\hline Article Info \\
\hline $\begin{array}{l}\text { Received: } \\
\text { 05 October } 2021 \\
\text { Accepted: } \\
\text { 29 October } 2021 \\
\text { Available Online: } \\
\text { 10 November } 2021\end{array}$ \\
\hline
\end{tabular}

"Phenotypic Stability Analysis for Seed Yield and its Associated Traits In advanced lines of Indian Mustard (Brassica juncea L. Czern and Coss)" was carried out to study the effects of different environments on seed yield and its associated traits, to estimate the magnitude of Genotype $x$ Environment interaction and to find out the most stable and high yielding genotype among the selected lines of Indian mustard under different environments of different topography, soil texture and prevailing climatic conditions of Manipur. Fifteen genotypes were evaluated in 3 different locations (Andro, Iroisemba and Senapati) in RBD with 3 replications over two seasons viz; Rabi 201819 and 2019-20. The environment wise ANOVA revealed highly significant differences among all the genotypes studied for all the 11 characters of seed yield and its associated traits. The pooled ANOVA also indicated significant differences among the environments, genotypes as well as genotype by environment (GXE) interaction for all the traits. Genotype $X$ Location interaction was observed as the main component for GXE interaction. Genotypes performed better in 2019-20 rabi season as compared to rabi 2018-19. Environment (E-5) i.e. Iroisemba, valley area was the best for expression of most of the characters studied. Stability Analysis using Eberhart and Russell indicated the significance of GXE (linear) for no. of siliqua/plant, no. of seeds/siliqua, siliqua length, no. of primary branches, no. of secondary branches, days to first flowering, days to $50 \%$ flowering, days to $80 \%$ maturity and 1000 seed weight except for plant height and seed yield per plot which shows the substantial amount of predictable G X E interaction for the expression of these characters in the selected genotypes. All the 15 genotypes were tested for 3 stability parameters, viz mean, bi and $\mathrm{S}^{2}$ di. The genotypes CAURMM-3, CAURMM-4, CAURM- 5, CAURM-4, PM25, CAURMM-1 and JM-1 were identified to be the high yielding and stable, hence they can be recommended for general cultivation under varied environments of Manipur. CAURM-1 CAURM-2, CAURM-3 had more stable characters although their yield was below the population mean, Therefore, proposed as promising genotypes for general cultivation under intensive input supply as they performed best in favourable environments, while NRCHB 101 found to be suitable for cultivation under poor environments. 


\section{Introduction}

In Manipur, Rapeseed mustard is one of the leading oil seed crop grown after harvest of rice. However, the production and productivity of this important oil yielding crop in the North-East region, Manipur in particular, is still far below the requirement. Several reasons are responsible for low productivity; the important one is unavailability of high yielding varieties with shorter and better stability and use of semi glutinous longer duration rice varieties that occupies the land up to November end resulting into limited land preparing period for rabi crops. Hence there is need for increasing the productivity of this crop through breeding of high yielding and stable varieties preferably with shorter maturity. The enhancement in production and productivity of the crop assumes significance, not only for farmer's viewpoint but also for all closely linked enterprises. Thus, there is compelling need to increase and stabilize the productivity of Indian mustard varieties to meet the growing demands for edible oil.

With these facts in view, the current research work was carried out to study the effects of different environments on seed yield and its associated traits, estimate the magnitude of Genotype $x$ Environment interaction and to find out the most stable high yielding one among the selected lines of Indian mustard under different environments.

\section{Materials and Methods}

The experimental material comprising of fifteen genotypes of Indian mustard, they were evaluated in randomised block design with three replications and spacing of $30 \mathrm{~cm} \mathrm{X}$ $10 \mathrm{~cm}$ during two consecutive rabi seasons under six environments namely; 201819(Andro, Iroisemba, Senapati), 201920(Andro, Iroisemba, Senapati) spread over different agro-climatic zones of Manipur. The sowing was completed during the second week of November at all the locations during each year and all crop management practices were followed to raise the crop.

Observations were recorded on ten randomly selected plants from each genotype in each replication with respect to nine qualitative traits. The stability parameters for different traits were computed using Eberhart and Russell model (1966).

\section{Results and Discussion}

The analysis of variance for pooled data indicated significant difference among the genotypes for all the eleven traits studied (Table1) revealing that there was inherent variability among the fifteen genotypes. Significant mean squares due to environments for all the eleven characters revealed that the six environments were variable hence played a significant role in the expression of eleven characters in the selected genotypes. Significant mean squares due to genotype $\mathrm{X}$ environment interactions confirmed the differential performance of Indian mustard genotypes across environments for all the eleven characters. Therefore, proved to be the Genotype $\times$ Environment $(\mathrm{G} \times \mathrm{E})$ interaction effects are of special interest for identifying the most suitable genotypes with respect to target environments, representative locations and other specific stresses.

Eberhart and Russell model (1966) reported that both linear and non-linear components are important for determining the differential genotypic response to different environmental conditions. Significant mean square due to environment linear for all the eleven traits studied indicated the presence of predictable differences over six environments. This could be attributed to variation in weather and soil conditions over different locations. 
Significant mean square due to genotype $X$ environment (linear) for no. of siliqua/plant, no. of seeds/siliqua, siliqua length, no. of primary branches, no. of secondary branches, days to $80 \%$ maturity and 1000 seed weight revealed a predictable differential response of genotypes across environments. While unpredictable response was observed for the characters plant height and seed yield per plot. Similar findings of significance variance for genotype $\mathrm{x}$ environment in Indian mustard has also been observed by Chauhan et al., (2010), Yadava et al., (2010), Sagolsem et al., (2013) Singh et al., (2016), Priyamedha et al., (2017) and Kumari et al., (2019). Also by Tadesse et al., (2018) in Ethopian mustard; Rezaizad et al., (2018), Brown et al., (2019) and Puhl et al., (2019) in oil seed rape.

Eberhart and Russell model 1966 suggested that an ideal genotype may be characterised as having high mean performance with unit regression coefficient $(b=1)$ and nonsignificant deviation from linear regression $\left(\mathrm{s}^{2} \mathrm{di}=0\right)$.

Accordingly the mean and deviation regression $\left(\mathrm{s}^{2} \mathrm{di}=0\right)$ are considered as measures of stability and regression coefficient is used for evaluating the genotypic response.

The genotype having regression coefficient (bi) value significantly above 1.0 (b>1) will have below average stability and specifically adapted to favourable environments as they are highly sensitive to changing environments. Regression coefficient significantly below 1.0 $(b<1)$ are genotypes having above average stability and they are well adapted to unfavourable environments.

Based on stability parameters (table 2a and 2b), genotypes CAURM-4, CAURMM-1, CAURMM-3, CAURMM-4, CAURM-5, PM 25, JM-1 and CAURM-2 were having bi value near to unity, $S^{2} \mathrm{di}=0$ and mean above or at par with population mean for seed yield per plot, hence they are stable and can be recommended for general cultivation in Manipur. However genotypes CAURM-1, CAURMM-2 and CAURM-3 had bi values near unity and mean values significantly lower than the population mean, thus these genotypes can be recommended for wide adaptation and cultivated under intensive input application as they were performing better in favourable environments. While NRCHB 101 had bi value significantly lower than unity and mean value above the population mean hence it was specifically adapted to unfavourable environments.

Based on the results, it appeared that no genotype could be found stable simultaneously for all characters across the environments. Each genotype was stable for one or more traits.

Thus, it is concluded that while selecting for stability in seed yield, various yield associated traits should also be taken into consideration. In the present study, CAURM-4, CAURMM1, CAURMM-3, CAURMM-4, CAURM-5, PM-25, JM-1, CAURM-2, CAURM-1, CAURMM-2 and CAURM-3 were having average stability with similar mean performance which could be considered as ideal genotypes for seed yield per plot while NRCHB 101 can be considered for unfavourable environments.

Five genotypes viz; CAURMM-1, CAURMM2, PM 25, NRCHB 101 and Kranti were stable for days to $80 \%$ maturity. Such genotypes matures within 115 days. Because of their shorter duration, they may be recommended for inclusion in the rice based cropping system in Manipur under wide cultivation. Early maturing genotypes of oilseed and pulses will solve the problems of low output of mustard cultivation facing by the farmers after longer maturity rice varieties. 
Table.1 Analysis of Variance (mean sum of squares) for phenotypic stability different characters in 15 Indian mustard genotypes (Eberhart and Russell, 1966).

\begin{tabular}{|c|c|c|c|c|c|c|c|c|c|c|}
\hline \multirow[b]{2}{*}{$\begin{array}{l}\text { Source of } \\
\text { Variation }\end{array}$} & \multirow[b]{2}{*}{ df } & \multicolumn{9}{|c|}{ Mean Sum of Square } \\
\hline & & $\begin{array}{l}\text { Days to } \\
80 \% \\
\text { maturity }\end{array}$ & $\begin{array}{c}\text { No. of } \\
\text { primary } \\
\text { branches }\end{array}$ & $\begin{array}{c}\text { No. of } \\
\text { Secondary } \\
\text { branches }\end{array}$ & $\begin{array}{l}\text { Plant } \\
\text { height } \\
\text { (cm) }\end{array}$ & $\begin{array}{l}\text { No. of } \\
\text { siliqua/ } \\
\text { plant }\end{array}$ & $\begin{array}{c}\text { Siliqua } \\
\text { length } \\
\text { (cm) }\end{array}$ & $\begin{array}{c}\text { No.of } \\
\text { seeds } \\
\text { /siliqua }\end{array}$ & $\begin{array}{c}1000 \\
\text { seed } \\
\text { weight }(\mathrm{g})\end{array}$ & $\begin{array}{l}\text { Yield/plot } \\
\text { (kg) }\end{array}$ \\
\hline Genotype(G) & 14 & $88.61 * *$ & $11.26^{* *}$ & $50.60 * *$ & $753.39 * *$ & $46507.45^{* *}$ & $2.02 * *$ & $7.34 * *$ & $4.29 * *$ & $286555.47 * *$ \\
\hline E+(gxe) & 75 & $41.72 * *$ & $0.69 *$ & $13.31 * *$ & $223.79 * *$ & $8491.60 * *$ & $0.14 * *$ & $2.33 * *$ & $0.48 * *$ & $111467.65 * *$ \\
\hline E (linear) & 1 & $1650.21 * *$ & $12.88 * *$ & $444.06 * *$ & $7540.37 * *$ & $224195.75^{* *}$ & $2.15 * *$ & $103.09 * *$ & $15.02 * *$ & $5736204.74 * *$ \\
\hline g x e (linear) & 14 & $46.48 * *$ & $0.85^{*}$ & $12.28^{*}$ & $83.67 \mathrm{~ns}$ & $13625.15^{* *}$ & $0.23 * *$ & $1.72 * *$ & $0.49 *$ & $22662.07 \mathrm{~ns}$ \\
\hline pooled deviation & 60 & $13.79 * *$ & $0.45^{* *}$ & $6.37 * *$ & $134.55 * *$ & $3698.71 * *$ & $0.09 * *$ & $0.79 \mathrm{~ns}$ & $0.24 \mathrm{~ns}$ & $38443.33 *$ \\
\hline Pooled error & 168 & 5.55 & 0.16 & 2.08 & 37.37 & 897.22 & 0.04 & 0.59 & 0.19 & 25850.51 \\
\hline
\end{tabular}


Table.2a Stability parameters for seed yield and its associated traits in 15 Indian mustard genotypes

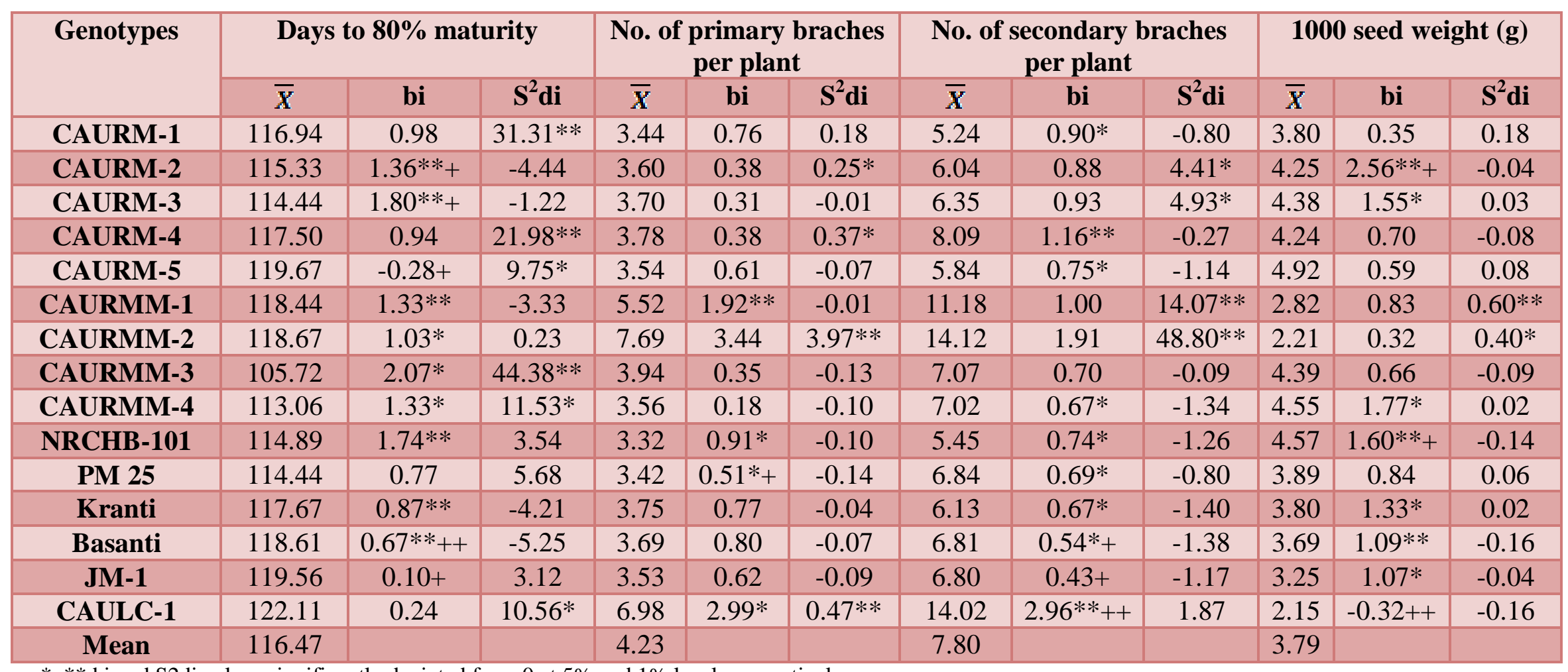

$*$, ** bi and S2di values significantly deviated from 0 at $5 \%$ and $1 \%$ levels respectively.

,+++ bi value significantly deviated from unity at $5 \%$ and $1 \%$ levels respectively. 
Table.2b Stability parameters for seed yield and its associated traits in 15 Indian mustard genotypes

\begin{tabular}{|c|c|c|c|c|c|c|c|c|c|c|c|c|c|c|c|}
\hline \multirow[t]{2}{*}{ Genotypes } & \multicolumn{3}{|c|}{ Plant height (cm) } & \multicolumn{3}{|c|}{ No. of siliqua per plant } & \multicolumn{3}{|c|}{ Siliqua length (cm) } & \multicolumn{3}{|c|}{ No. of seeds per siliqua } & \multicolumn{3}{|c|}{ Seed yield per plot (kg) } \\
\hline & $\bar{X}$ & bi & $S^{2} d i$ & $\bar{X}$ & bi & $S^{2} d i$ & $\bar{X}$ & bi & $S^{2} d i$ & $\bar{X}$ & bi & $S^{2} d i$ & $\bar{X}$ & bi & $S^{2} \mathrm{di}$ \\
\hline CAURM-1 & 134.96 & 1.54 & $645.79 * *$ & 148.62 & 0.68 & $1510.32 *$ & 5.23 & 0.82 & -0.02 & 13.24 & $0.92 *$ & -0.27 & 978.66 & $0.66^{*}$ & -9227.83 \\
\hline CAURM-2 & 133.17 & $1.32 * *$ & -2.13 & 132.85 & 0.53 & -31.90 & 5.86 & $1.32 * *$ & -0.03 & 12.69 & $1.39 *$ & 0.12 & 1231.41 & $1.20 * *$ & -1592.89 \\
\hline CAURM-3 & 132.84 & $1.66 * *$ & 3.625 & 142.31 & 0.09 & -358.23 & 5.28 & 0.38 & -0.01 & 12.77 & $0.93 *$ & -0.02 & 1091.93 & 0.84 & 16278.26 \\
\hline CAURM-4 & 134.79 & 0.89 & 16.63 & 170.76 & $0.63 *$ & -581.52 & 5.33 & $0.89 *$ & -0.03 & 13.33 & 0.96 & $1.73 * *$ & 1551.60 & $1.15 * *$ & -12232.90 \\
\hline CAURM-5 & 142.01 & $1.13 * *$ & -20.53 & 150.00 & $0.57 *+$ & -594.66 & 5.58 & $2.46^{*}$ & 0.01 & 14.15 & 0.52 & -0.21 & 1474.47 & 0.99 & 28191.86 \\
\hline CAURMM-1 & 147.19 & 1.39 & $162.41 * *$ & 345.42 & $2.96^{*}$ & $13753.28 * *$ & 4.62 & 0.33 & $0.27 * *$ & 11.56 & 0.43 & 0.70 & 1364.91 & $1.37 * *$ & -3976.99 \\
\hline CAURMM-2 & 136.63 & $0.93^{*}$ & -6.51 & 346.63 & 2.39 & $15279.65 * *$ & 4.21 & -0.73 & 0.03 & 11.46 & 0.84 & 0.49 & 1077.10 & $1.23 *$ & 8175.27 \\
\hline CAURMM-3 & 121.55 & $0.78 * *$ & -26.58 & 152.25 & $0.48 *++$ & -720.91 & 6.08 & 4.64 & $0.55 * *$ & 14.16 & $2.03 *$ & $1.33 *$ & 1694.82 & $1.22 * *$ & -5278.7 \\
\hline CAURMM-4 & 119.42 & 1.01 & $78.71^{*}$ & 154.84 & 0.46 & -126.94 & 5.65 & $1.43^{*}$ & -0.02 & 14.77 & $0.39 * *++$ & -0.57 & 1674.21 & $1.05^{*}$ & 11094.29 \\
\hline NRCHB-101 & 138.73 & 0.36 & 39.68 & 131.88 & $0.75 * *$ & -515.43 & 5.72 & 0.01 & -0.02 & 13.66 & $1.513 * *+$ & -0.42 & 1393.89 & $0.51 *+$ & -16617.9 \\
\hline PM 25 & 124.34 & $1.40 *$ & $56.74 *$ & 143.24 & $0.46^{*}++$ & -739.71 & 5.74 & $1.61 * *$ & -0.023 & 14.77 & $0.17+$ & -0.34 & 1429.00 & 0.66 & 14092.94 \\
\hline Kranti & 150.48 & 0.68 & $104.91 * *$ & 166.36 & $0.63 *$ & -506.96 & 5.35 & 0.65 & $0.08 *$ & 13.69 & $1.23 *$ & 0.27 & 1502.25 & 1.05 & $53258.38 *$ \\
\hline Basanti & 151.51 & 0.66 & $80.53 *$ & 187.60 & 0.54 & -313.27 & 5.16 & 0.398 & -0.02 & 14.35 & $1.28 *$ & 0.091 & 1475.24 & 1.13 & $65427.55^{* *}$ \\
\hline JM-1 & 158.98 & 0.31 & $66.98 *$ & 163.82 & $0.76 * *$ & -710.51 & 5.53 & $0.71 *$ & -0.03 & 13.19 & $1.473 * *$ & -0.37 & 1332.36 & $1.05 * *$ & -21171.2 \\
\hline CAULC-1 & 140.28 & 0.90 & $257.25^{* *}$ & 393.86 & $3.03 *$ & $16679.32 * *$ & 4.08 & 0.04 & -0.02 & 11.60 & 0.87 & 0.36 & 1127.80 & 0.91 & $62472.16^{*}$ \\
\hline Mean & 137.79 & & & 195.36 & & & 5.29 & & & 13.29 & & & 1359.98 & & \\
\hline
\end{tabular}

$*$, ** bi and S2di values significantly deviated from 0 at $5 \%$ and $1 \%$ levels respectively.

,+++ bi value significantly deviated from unity at $5 \%$ and $1 \%$ levels respectively 
Fig.1 AMMI biplot for Seed yield per plot in six environments

\section{AMMII 1 Biplot}

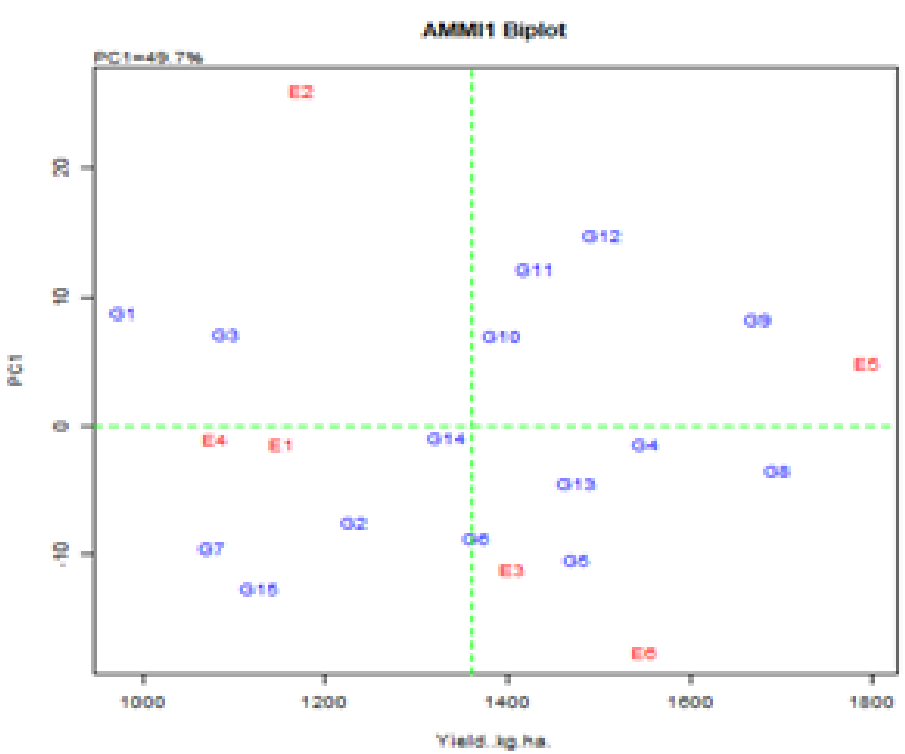

Genotypes:

$\begin{array}{llll}\text { G1- } & \text { CAURM-1 } & \text { G6- } & \text { CAURMM-1 } \\ \text { G2- } & \text { CAURM-2 } & \text { G7- } & \text { CAURMM-2 } \\ \text { G3- } & \text { CAURM-3 } & \text { G8- } & \text { CAURMM-3 } \\ \text { G4- } & \text { CAURM-4 } & \text { G9- } & \text { CAURMM-4 } \\ \text { G5- } & \text { CAURM-5 } & \text { G10- } & \text { NRCHB-101 }\end{array}$

\section{AMMI 2 Biplot}

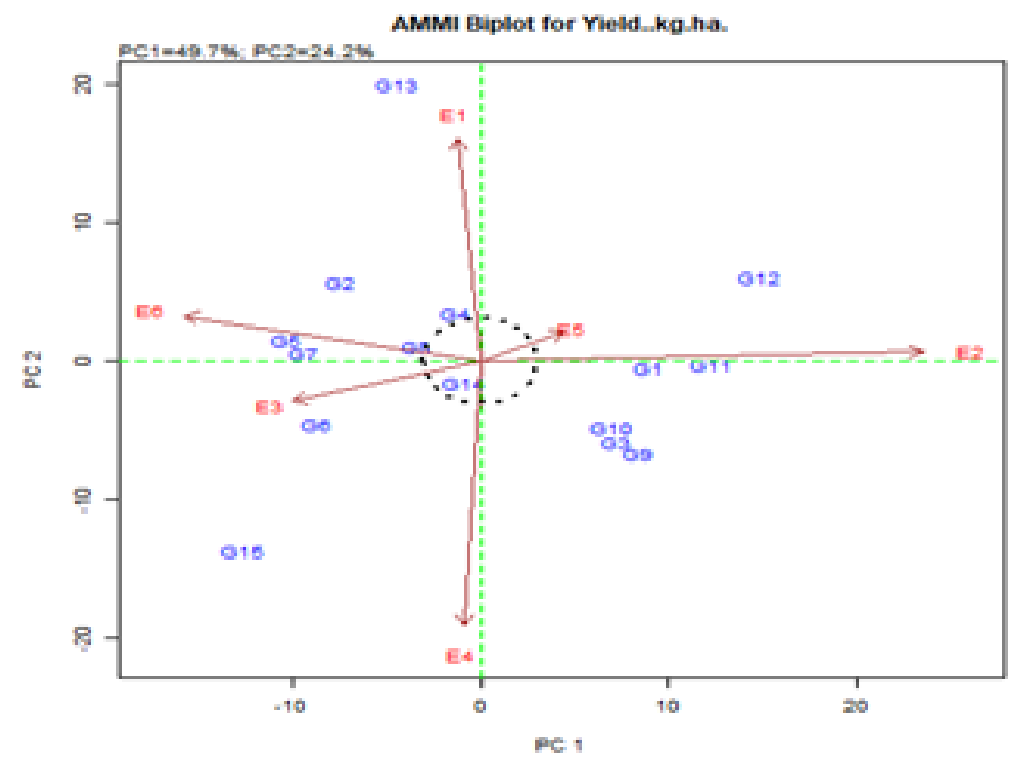

E1-Andro (Rabi2018)

G11- PM25

G12- Kranti

G13- Basanti

G14- JM-1

G15- CAULC-1
E2-Irosemba(Rabi 2018)

E3-Senapati(Rabi 2018)

E4-Andro (Rabi2018)

E5-Irosemba (Rabi 2018)

E6- Senapati (Rabi 2018) 
Seven genotypes; CAURM-1, CAURM-3, CAURM-5， CAURMM-3， CAURMM-4, Kranti, Basanti and JM-1 were stable genotypes for no. of primary branches per plant. Eight genotypes; CAURM-4, CAURM1, CAURM-5, CAURMM-3, CAURMM-4, PM-25, NRCHB 101 were stable genotypes for no. of secondary branches per plant. Seven genotypes viz; CAURM-2, CAURM-3, CAURMM-2, CAURM-4, NRCHB 101, CAURM-5, and CAURMM-3 exhibited stability for plant height. Eight genotypes; CAURM-2, CAURM-3， CAURMM-4, Basanti, CAURM-4, NRCHB-101, Kranti and JM-1 were stable for no. of siliqua/plant. Ten genotypes CAURM-2, CAURM-4, CAURM5, CAURMM-4, NRCHB-101, PM-25, JM-1, CAURM-1, CAURM-3 and Basanti exhibited average performance and stability for siliqua length. Seven genotypes viz; CAURM-5, Kranti, Basanti, CAURM-1, CAURM-2, CAURM-3 and JM-1 were stable genotypes for no. of seeds per siliqua. Ten genotypes viz; CAURM-1, CAURM-4, CAURM-5, CAURMM-3 and PM-25, CAURM-3, CAURMM-4, Kranti, Basanti and JM-1 were stable characters for 1000 seed weight. Based on the desirability characters, such stable genotypes can be selected and recommended to be involved in breeding programmes to develop high yielding and stable genotypes.

\section{AMMI stability Analysis (Fig. 1)}

AMMI Analyisis of Variance has indicated that the proportion of variation due to environment was highest for no. of seeds per siliqua and seed yield per plot indicating highly significant difference among environments for the expression of these traits. AMMI1 biplot and AMMI 2 biplot revealed that the six environments were unstable except E-5 which was stable for seed yield per plot; hence it is a desirable environment for the character seed yield per plot as it was stable and had highest seed yield per plot. Genotypes
CAURM-4, CAURMM-3 and JM-1 were the most stable genotypes for seed yield per plot, while all other genotypes were relatively stable except for Kranti, Basanti and CAULC1 which were unstable as indicated by their scattering away from the point of origin. (Fig. 1)

\section{Environmental Grading on the performance of Genotypes}

Grading environments according to their performance revealed that the best environment was E-5. This could be attributed to the climatic conditions such as annual average rainfall of $1469.7 \mathrm{~mm}$, cooler temperature, soil type (alluvial to loam black soils) and topography (valley) etc. of the location.

\section{Magnitude of GXE}

For seed yield per plot; genotypes Basanti, Kranti and CAULC1 had the highest magnitude of interaction with environments. While genotypes; JM-1, CAURM-4 and CAURMM-3 exhibited the lowest magnitude of interaction with environments, this implicates that these three genotypes viz; Basanti, Kranti and CAULC1 had highest differential performance across environments. EnvironmentsE-4, E2, E-6 and E-1 exhibited higher magnitude of interaction with genotypes. While E-5 and E-3 revealed lowest magnitude of interaction with the selected genotypes.

\section{References}

Allard R. W. and Bradshaw A. D. (1964). Implications of genotypes- environmental interaction in applied plant breeding. Crop Science, 4 : 503-508.

Allard R. W and Hansche, P. E. (1964). Some parameters of population variability and their implication in plant breeding. Advance Agronomy, 6 : 281-324. 
Brown, J. K., Beeby, R. and Penfield, S.(2019). Yield instability of winter oilseed rape modulated by early winter temperature. Scientific reports, 9(1): 1-9.

Chauhan, J. S., Meena, S., Singh, M. and Singh, K. H. (2010). Estimating genotype $\times$ environment interaction and stability parameters for oil and seed meal quality, seed yield and its contributing characters in Indian mustard (Brassica juncea). Indian Journal of Agricultural Sciences, 80(2): 110115.

Eberhart, S. A. and Russell, W. A. (1966). Stability parameters for comparing varieties. Crop Science, 6(1): 36-40.

Kumari, V., Jambhulkar, S., Chaudhary, H. K., Sharma, B. K., Sood, P., Guleria, S. K., Bala, A. and Sanju, S. (2019). Phenotypic stability for seed yield and related traits in Trombay mustard genotypes under north western Himalayas. Journal of Oilseed Brassica, 10(1): 33-37.

Mohammad, J. T., Ashwani, K. and Gupta, S. K. (2018). Phenotypic stability for yield and some quality traits in Brassica juncea L. International Journal of Current Microbiology and Applied Sciences, 7(2): 479-485.

Pike, E. and Silverberg, T. (1952). Designing mechanical computers. Machine Design, 24: 159-163.

Priyamedha, P., Kumar, A. and Haider, Z. A. (2017).Stability for seed yield and component traits in Indian mustard (Brassica juncea L.) under Jharkhand condition. Journal of Oilseed Brassica, 8(1): 37-42.

Puhl, L. E., Miralles, D. J., López, C. G., Iriarte, L. B. and Rondanini, D. P. (2019). Genotype X environment interaction on the yield of spring oilseed rape (Brassica napus) under rainfed conditions in Argentine Pampas. The Journal of Agricultural Science, 157(3): 235-244.

Rezaizad, A., (2018). Stability analysis of oil yield in different oilseed rape (Brassica napus L.) Genotypes in two normal and delayed sowing Date in Kermanshah Province. Journal of Crop Breeding, 10(25): 129-137.

Sagolsem, D., Singh, N. B., Devi, R., Wani, S. H., Haribhushan, A., Singh, N. G. and Laishram, J.M. (2013).Genotype x environment interaction in Indian mustard (Brassica juncea L. Czern and coss) under Manipur valley conditions. Indian Journal of Genetics and Plant Breeding, 73(3): 332-334.

Singh, V., Pant, U. and Bhajan, R. (2016). Physiological traits versus seed yield derived parameters based heat stress study in Indian mustard. Sabrao Journal of Breeding and Genetics, 48(2): 127-135.

Sutariya, D. A., Patel, K. M., Bhadauria, H. S., Vaghela, P. O., Prajapati, D. V. and Parmar, S. K. (2016).Genetic diversity for quality traits in Indian mustard (Brassica juncea L). Journal of Oilseed Brassica, 1(1): 44-47.

Tadesse, T., Sefera, G. and Tekalign, A. (2018). Genotypes X Environment interaction analysis for Ethiopian mustard (Brassica carinata L.) genotypes using AMMI model.Journal of Plant Breeding and Crop Science, 10(4): 86-92.

Williams, E. J. (1952). The interpretation of interactions in factorial experiments. Biometrika, 39(2): 65-81.

Yadava, D. K., Giri, S., Vasudev, S., Yadav, A. K., Dass, B., Raje, R. S., Vignesh, M., Singh, R., Mohapatra, T. and Prabhu, K. V. (2010). Stability analysis in Indian mustard (Brassica juncea) varieties. Indian Journal of Agricultural Sciences, 80(9): 761-765.

\section{How to cite this article:}

Danisa Dube, Th. Renuka Devi, Ph. Ranjit Sharma and Singh, N. B. 2021. Phenotypic Stability Analysis for Seed Yield and its Associated Traits in Advanced Lines of Indian Mustard (Brassica juncea L. Czern and Coss). Int.J.Curr.Microbiol.App.Sci. 10(11): 133-141. doi: https://doi.org/10.20546/ijcmas.2021.1011.017 